\title{
Chávez's Bolivarian Republic Viewed With a Quality Lens
}

\author{
Biff Baker \\ Metropolitan State University of Denver
}

This research looks at Venezuela using project and quality parameters of excellence with discussion on the practical implementation, success, or failures from a project and quality management perspective. For context, the introduction covers key Venezuelan leaders who preceded Chávez; the literature review dives deeper into the Bolivarian 21st Century Socialist experiment with foci upon measurable outcomes of key policies. The paper concludes with a theoretical assessment model with recommendations for future research focused upon project and quality assessments, not mere politics. The quality model and associated research questions will assist government and multinational corporation researchers, as well as students of international business to conduct grounded, fact-based assessments.

Keywords: Venezuela, Bolivarian, socialism, economic, collapse, project, quality, management

\section{INTRODUCTION}

The Republic of Venezuela is almost as old as the United States of America, having declared independence from Spain in 1811. The First Republic of Venezuela lasted from July $5^{\text {th }}, 1811$, to July $25^{\text {th }}$, 1812, but ended with a surrender to the Spanish military. Simón Bolivar reestablished the Second Republic of Venezuela in August 1813, however it fell in 1814. The Third Republic of Venezuela refers to the period from 1817 to 1819; then in 1820, an armistice was concluded between Spanish General Pablo Morillo, and the Revolutionary Simón Bolívar. Memory of the key victory of the revolutionary patriots over the Spanish military is still celebrated as Battle of Carabobo Day, on June $24^{\text {th }}$ annually. Simón Bolívar became the Supreme Commander of the Republic of Venezuela (Jefe Supremo de la República de Venezuela) from 1819 until 1830 . The remainder of the $19^{\text {th }}$ Century had a series of leaders that were authoritarian, many of whom were depicted as a caudillos or strongmen, who could impose order upon the young nation (Hamill, 1996; Ramirez, 2011).

President Juan Vicente Gómez was the catalyst for transitioning Venezuela from an agricultural economy to an oil rich exporter. He seized power in 1908 and remained in power until his death in 1935. During his regime, oil was discovered, providing this benevolent dictator the resources that transformed his country. Gómez was a nationalist who negotiated with European and American oil interests for the benefit of Venezuelan citizens and his supporters. From 1918 to 1958, international oil companies ran the Venezuelan oil industry, while the central bank maintained a fixed exchange rate with the U.S. dollar (USD). During this period, there were few impediments to trade, and the overall budget remained in surplus. Gómez continued to maintain good relations with foreign nations and eliminated all foreign indebtedness (Saavedra, 2003; Faria, 2008). So, what happened to this prosperity? 
Starting in the 1950s, the Venezuelan government began to diminish economic freedoms. Marcos Pérez Jimenez became president in 1953 and instituted a constitution that granted him dictatorial powers (Hollis, et.al., 2005). While Pérez Jiménez was in power, the economy of Venezuela developed rapidly due to rising oil prices. However, he led a repressive government using Dirección de Seguridad Nacional (National Security) to suppress criticism and imprison his opposition. During the 1950s, Marcos Pérez Jimenez's government: set up numerous regional development banks; nationalized CANTV, the telephone company; founded SIDOR, a state-owned steel company; built dams to generate electricity; established hotels across the country to develop a tourist industry; and, founded Instituto Venezolano de Petroquímica, a state-owned petrochemical company. Jimenez's government justified the creation of state-owned companies due to the apparent success of centrally planned economies such as the Soviet Union (Faria, 2008). However, he was deposed in a coup by the Armed Forces of Venezuela on 23 January 1958.

Rómulo Ernesto Betancourt Bello served as president from 1945 to 1948 and was elected once again from 1959 to 1964. Betancourt, an avowed communist turned Democratic Socialist, is remembered as father of the Venezuelan democracy, however, during his regime and each thereafter, the military operated behind the scenes (Saavedra, 2003; Acevedo, et.al., 2017). Betancourt moved Venezuela further away from laissez faire economics, as his administration:

- $\quad$ suspended Article 96 of the Constitution: "All can freely engage in the profitable activity of their choice, without any limitations other than those provided for in this Constitution and those established by law for security, health or other reasons of social interest."

- $\quad$ founded the Organization of Petroleum Exporting Countries (OPEC)

- created the Venezuelan Petroleum Corporation (Corporación Venezolana del Petróleo - CVP) to oversee the national petroleum industry and barred international oil companies from new concessions

- $\quad$ undertook land reform aimed at breaking up large landholdings (latifundia)

- established a central planning office called CORDIPLAN

- devalued the currency, raising the bolivar exchange rate from $\$ 3.30$ to 4.50 USD

- implemented exchange controls

- increased overall government expenditures

- $\quad$ tripled the income tax rate, raising it from 12 percent to 36 percent

- implemented price controls, such as rent-control law and prohibitions on eviction

- limited European immigration

Betancourt's key objective was the nationalization of the country's oil industry, but in the interim, he merely increased taxes on the oil companies. This movement toward socialism resulted in successive fiscal deficits that became a hallmark of Venezuela's public finance. Price controls and regulations damaged economic institutions; and real estate rental price controls destroyed the rental market, which eventually led to the creation of slums (Faria, 2008; O'Grady, 2018; Acevedo, et.al., 2017; Acevedo, et.al., 2019).

Raúl Leoni Otero was President of Venezuela from 1964 until 1969, and as a charter member of the Acción Democrática (AD) party, he held similar beliefs and goals as Betancourt. Leoni enforced the importsubstitution policy that increased the Venezuelans' cost of living and misallocated resources; his administration also fortified and augmented the unionized labor force. Rafael Antonio Caldera Rodríguez succeeded Leoni, and he made his impact upon the economy by requiring all private companies to have a majority ownership by Venezuelans (Faria, 2008). Caldera nationalized the gas industry, increased taxes on oil production, and enacted tougher laws to regulate the U.S. oil companies operating in Venezuela. In 1971, he raised the oil profit tax to $70 \%$ thereby making investment less attractive to foreign investors (Sangwani, 2016).

Carlos Andrés Pérez Rodríguez was elected president in 1974 and served until 1979. The huge increases in the price of oil due to the historic oil embargo, led to a successful economy during which his administration: substantially increased government debt; established new state-owned companies; nationalized the oil and iron industries; nationalized the central bank, and replaced the board with cabinet members, thereby wiping out the bank's independence. These moves marked the commencement of a patrimonialism, which decreased traditional limitations on the exercise of authority, and consequently 
increased government corruption. The national assembly passed an 'enabling law' that permitted rule by decree; so, Pérez implemented the first-ever minimum wage, and mandated salary increases. To his dismay, Pérez's reputation was tarnished by accusations of excessive, disorderly, government spending. These policies and programs, plus infrastructure improvements as well as funding social welfare and scholarship programs, involved massive government spending (Faria, 2008; Ellner, 2008; O'Grady, 2018).

Luis Antonio Herrera Campins succeeded Pérez from 1979 to 1984. Herrera continued Pérez's policy of borrowing on a world market that was awash with petrodollars; so, by the early 1980s Venezuela accumulated debt of more than \$20 billion. After more than doubling Venezuelan external debt, in 1983 he devalued the currency exchange to over 7 bolivars per dollar. President Herrera reinforced price controls, which applied to almost everything to include cement, hotels, banking, parking lots, as well as perishables such as meat, milk, and sugar. His administration moved public funds into agricultural and industrial projects, paying generous subsidies and controlling the prices of many goods. By the time Herrera left office, the economy was in meltdown, poverty and hardship were widespread, and in December 1983, the voters ejected his party from office (Faria, 2008; O'Grady, 2018).

Carlos Andrés Pérez Rodríguez is remembered for a period of prosperity in the 1970s that coincided with high oil prices; as a result, he was re-elected president and served from 2 February 1989 to 21 May 1993. Unfortunately, the oil embargo and high prices of the 1970s did not exist during his second term. So, with mounting debt, at the start of his second presidential term, Pérez accepted an International Monetary Fund (IMF) proposal known as the Washington consensus (Cole, 2010). The IMF offered Venezuela a loan for $\$ 4.5$ billion USD for accepting a proposal that was focused on fiscal policy discipline. Trinkunas (2002) identified that after the drop in oil prices, the socio-economic balance that was based on maintaining political stability through state redistribution of oil revenues, became unsustainable. For instance, the number of Venezuelans living in critical poverty expanded from 32.6 percent at the beginning of the 1980s to 53.7 percent in 1989 prior to his election! The newly elected President Perez was faced with an acute balance of payments crisis and the accelerating collapse of state institutions. Therefore, President Perez adopted a radical structural-adjustment plan called the Great Turnabout (El Gran Viraje).

- This plan simultaneously eliminated price and currency controls, raised interest rates, reduced tariffs, and began to privatize state industries and deregulate the economy.

- The result was that in 1989 alone, the rate of inflation surged to 80 percent, the gross domestic product declined by 10 percent, and personal income dropped by 14 percent.

- In addition, the wages, and benefits of officers, like those of most Venezuelan citizens, failed to keep up with the inflation of 1989-1990, which topped out at over 100 percent.

Poorly implemented neoliberal reforms caused an immediate increase in the cost of gasoline for consumers, as well as fare increases on public transport, which resulted in massive popular protests and lootings, now known as the "Caracazo" - when plundering and violence continued for days. Pérez called out the military to end the violence, which left hundreds of dead (Trinkunas, 2002; Kurmanaev, 2015). In addition to the inflation and wage issues, many in the military resented being used against their own citizens, thusly creating a trigger point for the two failed coup attempts in 1992 (Bak, 2001; Sylvia, et.al., 2003; McCarthy-Jones, et.al., 2011; Almandoz, 2017). Sylvia and Danopoulos (2003) determined that these coups failed due to:

- Units not attaining objectives such as control of the media;

- A failure to neutralize President Perez and other key leaders;

- Senior officers remaining loyal to the Perez administration; and,

- Misjudging international environment and citizen attitudes.

Although both coups d'état failed, they set the stage for a further political, rather than military movements. Chávez and his supporters took steps transform Moviemento Bolivariano Revolutionario (MBR) from a military organization to a political movement known as the Fifth Republic Moment (MVR). (Trinkunas, 2000; Hawkins, 2003; Kirk, 2003; Sylvia, et.al., 2003; Almandoz, 2017). 


\section{Socialism}

Venezuela began moving away from laissez faire economics in 1953, and almost every president thereafter expanded the national government's role in economics with support of the population. For instance, from 1953 to 1980, Venezuelan miners campaigned for adult suffrage, land reform, rural education, and indigenous rights as part of the Revolutionary Nationalist Movement; and they spread their democratic socialist message through community owned radio stations until the collapse of tin industry in the 1980s (Artz, 2016). But, before conducting the literature review, we must first define socialism:

- Martin (1911) queried leading minds and determined that socialism includes public ownership of nearly all the means of production; operation of the means of production by public officials; distribution of income based upon rules determined by the community, and private ownership of the income once distributed.

- Capitalism is defined by private property rights and voluntary exchange; whereas socialism is defined by the collective ownership of the means of production (that the state manages) (Butgereit, et.al., 2011).

Using either definition, one must concede that Venezuela already had 40 years of incremental socialism with little institutionalized experience in free markets prior to the election of Chávez (O'Grady, 2018). So, using a grounded theory investigation we ask: If Venezuela already leaned heavily toward socialism from 1952 to 1998, what changed with the election of Chávez? The following literature review is focused upon the years that Chávez served as president and the outcomes or results of his key policies to investigate this inquiry.

\section{LITERATURE REVIEW}

Influenced by the nineteenth-century Venezuelan revolutionary Simón Bolivar, Hugo Rafael Chávez Frías and some younger military officers, created the leftist Revolutionary Bolivarian Movement-200 in 1983. MBR-200 was created with an aim to correct perceived corruption and inequities in Venezuela. The movement borrowed heavily from Bolivar's belief in a unified Latin America, but it also drew inspiration from the leftist Peruvian military junta during the 1970s. Members of the MBR-200 advocated for a strong Bolivarian democracy, and were opposed to political corruption, neoliberal economic policies, and foreign influences (Trinkunas, 2002).

The MBR-200 movement grew slowly in the 1980s, but it gained momentum after the Caracazo riots of 1989. Between 1989 and 1992, MBR-200 gained many followers who opposed Pérez's policies. In February 1992, Hugo Chávez's Bolivarian Revolutionary Movement-200 attempted to overthrow President Carlos Andres Perez, but they failed. After his subsequent arrest, Chávez appeared on national television directing rebel detachments to cease fighting; then he and the other conspirators were imprisoned. Later that year, although Chávez was still in jail, a second coup d'état was attempted, but it also failed. Pérez intensified the monitoring of the officer corps, and any officer of dubious loyalty was expelled from the armed forces. Nonetheless, Chávez had become a symbol of hope for the oppressed as reformist fervor spread (Trinkunas, 2002; Hawkins, 2003; Upchurch, et.al., 2014; Acevedo, et.al., 2017; Almandoz, 2017).

Rafael Antonio Caldera Rodríguez was elected to the presidency amidst an economic recession and high inflation, a huge banking crisis, and steep decrease in oil prices. Amidst this economic turmoil, President Caldera pardoned Chávez and his companions in 1994. Caldera encouraged the newly freed men to pursue change through politics rather than armed insurrection. Caldera's priorities were restoring the economy and rooting out corruption. Similarly, Chávez as an outsider ran for president in 1998, promising to end corruption, vanquish poverty, and scrap Venezuela's old political system. Chávez's success against entrenched political parties was in part due to the failure of formal democratic institutions to reflect the public will by reinvesting oil revenues in the social economy (Trinkunas, 2002; Hawkins, 2003; Gibbs, 2006; Upchurch, et.al., 2014). 


\section{Chávez First Term as President: 1998-2000}

Hugo Rafael Chávez Frías founded the Fifth Republic Movement (Movimiento Quinta Republica $M V R$ ) political party and was elected president of Venezuela in 1998 receiving 56.2\% of the vote. After taking office in February 1999, Chávez launched Plan Bolivar 2000, which used about 40,000 Venezuelan soldiers to engage in door-to-door anti-poverty activities that included food distribution in slum areas, mass vaccinations, as well as education programs. All these programs resonated with his supporters as a commitment to place human needs first (DOS, 1999; Gibbs, 2006; Upchurch, et.al., 2014).

Since 1811, Venezuela had 27 constitutions typically tailored to the beliefs of the caudillo in charge (Acevedo, et.al., 2019). Similarly, in December 1999, 70\% of the voters approved a new constitution that increased the presidential term to six years, expanded presidential powers (to include personalized control of the military by the president), converted the two-house National Assembly into a one-house legislature, and outlawed government financing of political parties' electoral campaigns. This new constitution expanded transparency of the democratic processes that included public institutions, political parties, and labor unions as well as restoration of the independence of the judiciary. It also referred to a fourth power called the 'Citizens Power,' that would function as a council to monitor the public sector and fight against corruption. Also, per Chávez's request, the country was renamed the Bolivarian Republic of Venezuela (República Bolivariana de Venezuela).

During Chávez's first term, Venezuela experienced a recession, with oil prices dropping to their lowest in 24 years, an unemployment rate of $15 \%$, as well as a 7\% drop in Gross Domestic Product (GDP). To counter bad economic news, Chávez appeared on television and radio with inflammatory rhetoric that targeted the media, businesses, and foreign countries often demonizing American imperialism and neoliberalism (McCarthy-Jones, et.al., 2011). Chávez used semi-theological rhetoric about reinventing individuals, so that a new society could be built based upon a new man, new society, and new ethos (Wilde, 2018). This concept reappears much later in Mission Vuelvan Caras goals that emphasized values of altruism, solidarity, and social utility of work as alternatives to both consumerism and individualism (Upchurch, et.al., 2014). Overall, this polemic worked, for Chávez was reelected in 2000 with 59.8\% of the vote. (Bak, 2001; Hawkins, 2003; Gibbs, 2006; Gott, 2008; Upchurch, et.al., 2014; Almandoz, 2017).

\section{Chávez Second Term as President: January $10^{\text {th }}, 2001$, to January $10^{\text {th }}, 2007$}

Initially, Chávez was a dark horse during the election process, but the voters still desired radical change from the corruption of the past. The leading candidate was Irene Saez, a mayor, and former Miss Universe. However, when Ms. Saez accepted the endorsement of the Christian Democrat Party (COPEI), the voters turned out against her, which propelled Chávez ahead (Hawkins, 2003).

Shortly after the election, Chávez's popularity dropped in part due to his expanding relationship with Fidel Castro; many citizens believed that Chávez was attempting to remake Venezuela in Cuba's image. The first major national protest was opposed to educational curriculum that was viewed as Cuban-produced indoctrination. Middle-class parents did not want the Cuba's socialist propaganda in their children's' textbooks, so they lead a successful protest chanting "Con mis hijos no te metas" (don't mess with my children). Their protests were so effective that Chávez recalled the Cuban textbooks (Nelson, 2009; Nelson, 2021).

Venezuela delivered 38,000 to 96,000 barrels of oil per day to Cuba at very favorable prices as part of the Alianza Bolivariana para los Pueblos de Nuestra América (ALBA Alliance) in exchange for support from Cuban healthcare workers and teachers (Gibbs, 2006; Britanica, 2013). Hence, Chávez hired 11,000 Cuban medics to improve health of the lower-class citizens; this too was opposed by many in the middle class who claimed that poorly trained Cuban immigrants were practicing medicine illegally (Ceaser, 2004). But, by 2005, the Cuban supported Barrio Adentro Mission had more than 20,000 Cuban doctors, health workers and physical trainers assisting poor communities as oil-for-services trade (Ceasar, 2004; Gibbs, 2006; Britanica, 2013; Almandoz, 2017).

Chávez had plans to expand anti-poverty activities that his administration started under Plan Bolivar 2000 , but he needed more funding for the expansion of his social welfare programs. The provider of most of the government's spending money was the immense state oil company, PDVSA - Petróleos de 
Venezuela Sociedad Anónima (Gott, 2008). So, Chávez plotted to increase government revenues from PDVSA. On April 7, President Chávez fired the CEO of PDVSA, and replaced numerous long-serving petroleum professionals with his political followers. Hawkins (2003) identified that many Venezuelans perceived PDVSA as one of the few government companies that ran efficiently, and it was seen as a source of pride and national wealth. After Chávez publicly fired the top managers ... the opposition mobilized several demonstrations in favor of PDVSA leadership and against the government. The demonstrations culminated in a protest march of over one-million citizens of Caracas.

The pro-PDVSA march started moving toward the presidential palace; then, sharpshooters fired on the crowd killing about 20 people. Chávez requested troop reinforcements, but his generals declined, and they asked for his resignation; amazingly, Chávez returned to power within 48 hours. Protests and strikes over the PDVSA continued for several months culminating in a National Strike and an oil stoppage from December 2002 to January 2003. Hawkins (2003) determined that Chávez not only remained adamant in the face of these setbacks but set out to punish the opposition by firing over one-third of PDVSA's workforce and calling on judges to punish the leaders of the opposition; his economic ministers froze the exchange rate and began imposing price controls to compensate for the fiscal deficit and the downward spiral of the economy.

Chávez removed much of PDVSA's technical expertise; this resulted in a lower output of about 300,000 barrels per day between 2001 and 2003. The tension between the PDVSA oil company and the Chávez administration is an example of the clash between two world views. In a neoliberal economic worldview, espoused by Rafael Caldera's 'Apertura' (openness), businesses should be privatized, and the economy open to foreign investment. However, in Chávez's socialist worldview, the government should own or control the means of production. Vivoda (2009) showed that when prices rise, host governments rethink their contracts and seek higher taxes and royalties; hence, rising oil prices were instrumental in Chávez getting more favorable investment conditions. In the fullness of time, Chávez won the stand-off with PDVSA and his administration raised the royalty rate from $16.7 \%$ to $30 \%$. In addition, Chávez decreed that all future foreign investment would be developed as joint ventures and the state would always have a $51 \%$ stake (Gott, 2008; Denning 2018).

We now review Chávez's evolving goals using a social, political, and economic framework. We identify that Chávez goals were evolving, because he had broad ideas of what he wanted to accomplish during his first term, but many of his ideas did not turn into plans, policies, or procedures until his second term, after the increase in royalties.

\section{Social Goals}

Social goals were spelled out prior to being elected in 1998. Chávez started with his vision in the 1983 Revolutionary Bolivarian Movement-200 (MBR-200) with an aim to correct corruption and inequities in Venezuela; more specifically, he opposed political corruption (real or perceived), neoliberal economic policies (e.g., market-oriented reform policies), foreign influences (despite that oil exports depend on foreign markets) and favored a strong democracy that supported nationalism and patriotism. Chávez prioritized response to the demands of Venezuela's poor majority, to the exclusion of the middle and upper classes (Gibbs, 2006). Central to the social mobilization were the Comites de Tierra Urbana (CTU) and communal councils (consejos comunales), or neighborhood associations, which were envisioned as corner stones of the bottoms-up focus of his Bolivarian socialism (Trinkunas, 2002; Gibbs, 2006; Gott, 2008; Rivers, 2011; Gates, 2014; Bruce, 2015).

\section{Political Goals}

Political goals during his first term included the rewrite and approval of a new Venezuelan Constitution, and of course, getting reelected. During his second term in office, Chávez was opposed by the middle class and upper class in many areas, so Chávez championed yet another Constitutional change. Chávez opposed Article 115 of the 1999 Constitution that guaranteed a right to private property, because it slowed many of his economic goals. Chávez had to find a way around that Constitutional guarantee to private property. Secondly, many of Chávez goals were taking a long time to implement, so he championed a new provision 
that would have permitted Chávez to submit himself for indefinite presidential elections; however, this was defeated in the Referendum on Constitutional Reform in 2007 (Gott 2008; Rivers, 2011).

\section{Economic Goals}

The economic grand strategy during Chávez's first term was limited. Since his voter-base consisted of the poor, Chávez's priorities were evidenced in Plan Bolivar 2000, which included road building, housing construction, and mass vaccinations. Rivers (2011) identified that during Chávez's second term as president, he solidified his top five priorities - eliminating food dependence, developing infrastructure, managing oligarchs, developing cooperatives, and expropriation as discussed below.

\section{Eliminating Food Dependence}

Venezuela has always relied on food imports; hence, Chávez intended to make Venezuela more selfsufficient in agriculture, since $60 \%$ of food was imported. Chávez was able to pass the Law of Land and Agrarian Development in 2001, which provided the legal framework to redistribute land. Page (2010) determined that Chávez's lofty goal was dependent upon training people in agricultural production and shifting to a socialist production model. Unfortunately, the initial volunteers for the Vuelta Al Campo (VAC) program did not receive critical training and resources as promised. For instance, Fundo Revolucion started with 117 families in five cooperatives, and shrunk to three cooperatives with a total of 16 members in less than 2 years. The VAC program remained in a Catch-22 loop wherein volunteers did not want to relocate to rural areas without infrastructure; but the government did not want to provide resources without enough volunteers. So, despite numerous Chávez supporters, the VAC was destined to fail due to multiple factors: too few volunteers, too little training, poor environmental and soil conditions, as well as slow infrastructure development (Page, 2010).

\section{Developing Infrastructure}

The development of roads, water utilities, and power companies would help remote areas connect with urban markets. Plan Bolivar - 2000 was a civil-military plan which involved over 40000 soldiers cleaning up streets and schools, fighting endemic diseases, and rebuilding social infrastructure in poor urban and rural areas; however, there was not a huge focus on infrastructure improvements. In addition, the more that was spent on social-welfare programs, the less was spent on the necessary improvements to oil infrastructure (DOS, 1999; Gibbs, 2006; Avilés, 2009).

\section{Managing Oligarchs}

Chávez recognized that his base consisted of the lower socio-economic class, so he often demonized the wealthy. However, by demonizing and attacking the wealthy land and business owners, large landowners as well as National Labor organizations opposed land reform laws as a violation of their private property rights. Chávez destabilized the potential growth and reinvestment in his own economy. Critics of the revolution claim Chávez built his political base by purchasing the support of the poor (Gibbs, 2006). In addition, critics complained that the continuing uncertainty about the Bolivarian economic model adversely affects private investors, both at home and abroad. Expropriations, socialist rhetoric, verbal attacks against the private sector, and land invasions do not stimulate private investment (Gott, 2008; Rivers, 2011).

\section{Developing Cooperatives}

Cooperatives are groups of people who work collectively and share profits. Cooperatives existed for many decades before Chávez rose to power, but he saw them as central to his Bolivarian strategy, so he provided seed money to expand the number and scope of cooperatives throughout every sector of the economy. The number of cooperatives expanded from 762 co-ops (with 20,000 members) in 1998 to over 100,000 coops (with 1.5 million members) in 2006 (Gott, 2008). According to SUNACOOP (the national cooperative supervisory institute) by 2008, there were 262,904 cooperatives officially registered (Azzellini, 2009). Cooperative success was highlighted by the Association Civil Empresa Campensina Chuao, which 
was able to increase cacao production by $300 \%$ between 2005 to 2007 (Rivers, 2011); however, this type of success was not true of most cooperatives.

\section{Expropriation}

In 2005, Chávez declared that 136 closed companies were under review for possible expropriation; however, his list targeted 1,149 sites in the whole country (Azzellini, 2009; Upchurch, et.al., 2014). The core of Chávez's socialist beliefs was to take wealth out of the hands of the few wealthy and redistribute it for the benefits of the many poor (Gibbs, 2006). Researchers reported that Chávez nationalized or expropriated many industries (Azzellini, 2009; Batta, et.al., 2014), for example:

- Orinoco oil field projects (multinational petroleum companies had majority stakes)

- Electricidad de Caracas in 2007, the country's largest private electricity provider

- Telefonos de Venezuela (CANTV), the country's major provider of telephone services

- Siderurgica del Orinoco (SIDOR), the steel company

- Venepal (now called Invepal), a paper factory

- Constructora Nacional de Válvulas (now Inveval) producing valves mainly for the oil industry

- three million hectares of land

- about one quarter to one-third of the banking sector

- TELESUR, a pan-American news channel

- Villa del Cine movie studio

Chávez's five economic priorities were interwoven, for instance, decreasing food imports depends upon an improvement in roads to get home-grown food to market. Food self-sufficiency depends on full utilization of land, much of which belonged to the oligarchs; yet the expropriation of land from oligarchs was stymied by Article 115 of the 1999 Constitution. Cooperatives in both rural and urban areas depended upon acquiring capital and natural resources, which were often in the hands of the oligarchs as well.

Chávez promoted Constitutional Reform of 2007, which would have helped him achieve his authoritarian social, political, and economic goals; but this referendum with sixty-nine new or revised articles to the Constitution was defeated by voters $49 \%$ to $51 \%$ (Gott 2008; Rivers, 2011). Leading up to this referendum, there were several reasons for defeat: the voters became aware of government failings despite large amounts of money spent; decreased support by governors and mayors, due to a perceived threat to their existing powers; lack of support from many evangelicals, due to a perceived expansion of gay and lesbian rights; and many in the military became wary of Chávez's relationship with Cuba (Bak, 2001; Trinkunas, 2002; Gott, 2008, Page, 2010; Rivers, 2011; Nelson, 2021).

Despite the lack of success in many fronts, and the defeat of the Constitutional referendum, Chávez remained in power due to one thing: a massive increase in the price of oil. As one can see in Figure 1, between 1999 and the 2008 election cycle, the price per barrel of oil increased more than 400\%. Hence, cash-rich Venezuelan regime was able to implement many plans that would have been impossible to fund during the 1990s (Gutierrez, 2017). 


\section{FIGURE 1 \\ HISTORICAL CRUDE OIL PRICES}

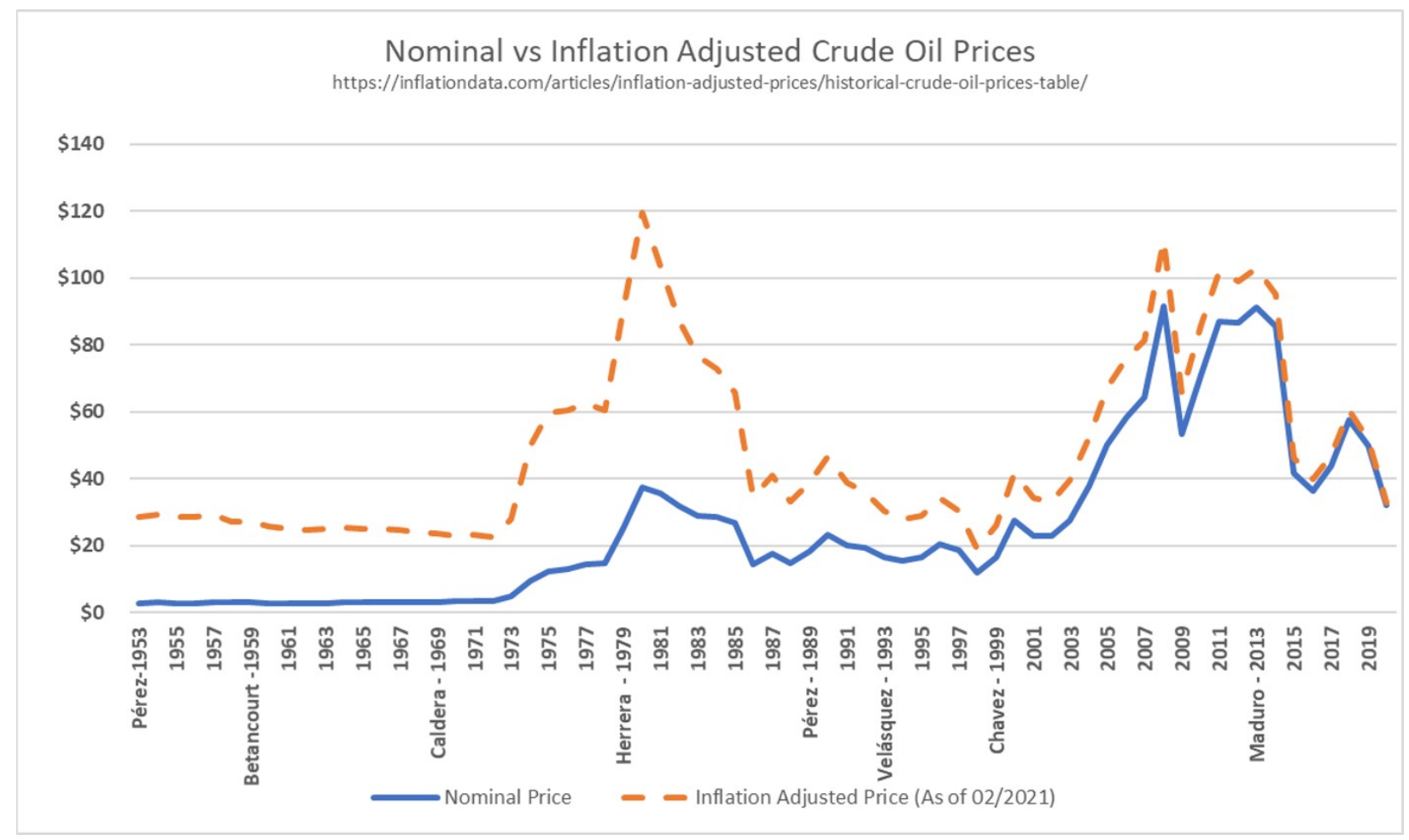

Hugo Rafael Chávez Frías was re-elected in 2006 with $62.8 \%$ of the vote. The huge increase in oil prices that facilitated a significant increase in government spending on social programs, plus the opposition's inability to coordinate assured his reelection (Vargas, 2014). Nominal oil prices swelled from \$16.56 USD per barrel in 1999, when Chávez first became president; to \$91.48 USD per barrel by 2008; so, the value of oil exports increased more than $400 \%$ as well. Chávez could claim credit for a reduction in inequality, since household poverty and household extreme-poverty rates were in 2003 respectively, 55.1\% and $25.0 \%$, but by 2008 , decreased to 27.5 and $7.6 \%$ respectively; in addition, the unemployment rate of $18.0 \%$ in 2003 was reduced to $7.4 \%$ by 2008 (Muhr, 2012; Gutierrez, 2017).

\section{Chávez Third Term as President: January $10^{\text {th }}, 2007$, to January $10^{\text {th }}, 2013$}

In 2007, Chávez's re-election brought about a more open discourse about socialism; he had been in office seven years before formally announcing his vision of $21^{\text {st }}$ Century Socialism. Chávez did so on January 30, 2005, during a speech to the 5th World Social Forum, but was sparse in detail. On May 13, 2006, at the Linking Alternatives II Conference in Vienna, Chávez stated:

"We have assumed the commitment to direct the Bolivarian Revolution towards socialism and to contribute to the socialist path, with a new socialism, a socialism of the 21 st century, which is based in solidarity, in fraternity, in love, in justice, in liberty, and in equality, [and that we must], transform the mode of capital and move towards socialism, towards a new socialism that must be constructed every day."

Muhr (2012) identified that the Bolivarian government's National Development Plan (NDP) 2007-13 associated direct democracy with a sovereign people who can run the state by themselves. The Venezuelan NDP envisioned four primary mechanisms to install direct democracy for a reduction in social and economic inequality: 
- Recall referendum permitted the people to recall or revoke any politician, once half of their term in office had elapsed;

- Social street parliamentarianism to promote the populaces' involvement in self-government via co-legislating;

- Communal councils envisioned as embodiment of Popular Power, e.g., social ownership was of two types: (1) managed by the state; or (2) managed by the people through their community councils, communes, and communal cities.

- Communal direct social property enterprises or social production companies (EPS) that weigh social profit more than private profit, and direct production toward social needs rather than capital accumulation (Azzellini, 2009; Muhr, 2012).

Most of the barrios in Caracas were built on public land. So, Chávez encouraged people to organize urban land committees or Comites de Tierra Urbana (CTU). Each CTU covered up to 200 homes with boundaries defined by the community itself. Once the CTUs had organized, the authorities would process claims and grant titles to the individual occupants. Therefore, CTUs illustrated precisely that combination of initiative from above and spontaneous organization from below using the Popular Power mechanisms (Bruce, 2015).

Survival of Chávez's presidency depended heavily upon mobilization of the citizens. Therefore, Mission Vuelvan Caras was created to assist the government in future development promoting the following six principles: economic development should be endogenous; state assumes a proactive economic role via nationalization of strategic industries; state promotes participatory democracy through Communal Councils; civic engagement of the people in the revolutionary process; replace market-led mechanisms with alternative forms of social relations based on the socialization of revenues; and the values of altruism, solidarity and social utility of work should be promoted as an alternative to both consumerism and individualism(Upchurch, et.al., 2014).

In addition to Misión Vuelvan Caras, researchers identified an integral set of over thirty universally accessible misiones (missions) that were central to participatory democracy in Venezuela (Muhr, 2012; Upchurch, et.al., 2014; Bruce, 2015). The spending on many missions expanded significantly as oil prices rose:

- Misión Identidad (Mission Identity) provided over five million previously disenfranchised people with legal citizenship;

- Misión Mercal distribution of subsidized food in government sponsored cooperatives;

- Misión Barrio Adentro (inside the Barrio), Milagro (Miracle) and Sonrisa (Smile) provision of free health care, including dental treatment brought assistance to almost every poor neighborhood in Venezuela and was assisted by over 20,000 Cubans;

- Misión Madres del Barrio (Mothers of the Neighborhood) to assist women's rights;

- Misión Negra Hipólita mobile care centers cater to those living on the street, victims of HIV/AIDS, etc.;

- Misións Robinson I, II, III, Ribas, Che Guevara and Sucre provide education at all levels with the Bolivarian government claiming that Mission Robinson-1 taught 1,314,788 Venezuelans to read and write in less than a year and a half [Note: 9 years of education had already been mandatory in Venezuela since 1980 (Patrinos, et.al., 2005)];

- Misión Música provided deprived children free classical music education;

- Misión Árbol conducted reforestation;

- Misión Revolución Energía (Energy Revolution) was focused upon energy saving and renewable energy technologies.

\section{Cooperatives}

Rivers (2011) found that cooperatives were critical to Bolivarian Socialism because they facilitated economic growth at the lowest levels, and typically used a bottoms-up approach for production, management, and growth. Unfortunately, their long-term sustainability is in doubt. In some instances, the price of the product did not cover the cost of production; whereas in other instances some associations had 
as much as triple the number of employees that might be needed by a privately owned firm; in addition, some agricultural cooperatives could not compete due to higher price, and poor packaging or labeling (Rivers, 2011; Upchurch, et.al., 2014; Bruce, 2015).

Upchurch, et.al. (2014) reported that registered cooperatives grew from just 400 in 1998 to 131,050 in 2006 - but 60 to $70 \%$ were not economically active. Page (2010) investigated representation programs finding that many failed due to a lack of training, a lack of infrastructure, and often poor soil. Bruce (2015) also found that cooperatives often lacked training, lacked resources, lacked infrastructure, and often did not create enough revenue to play all workers or reinvest in the business itself. Azzellini (2009) reports that out of the 262,904 officially registered cooperatives, only 70,000 were both operational and legally certificated; the remaining cooperatives were created just-in-case they were needed, but most were not yet running. Cooperatives were seen as a key instrument to transition to an endogenous model of economic development; they were intended to raise people's living standards exempt of capitalistic exploitation. But due to a lack of administrative and technical skills, the cooperatives failed to meet the broad goals of $21^{\text {st }}$ Century Socialism and could not compete with capitalist alternatives (Upchurch, et.al., 2014). The government explanation for the failure of tens of thousands of cooperatives was greed; however, struggles of everyday life such as insecure employment, multiple jobs, family obligations and merely the precarious nature of life in the barrio interfered with many of Chávez's lofty goals, simply because workers had other priorities (Ellner, 2010; Upchurch, et.al., 2014; Wilde, 2018).

\section{Chávez Fourth Term as President - 2013}

Chávez was to be sworn in on January $10^{\text {th }}, 2013$, but due to his cancer treatment, the inauguration was postponed. Chávez died in Caracas on March 5 ${ }^{\text {th }}, 2013$ (Castillo, 2013).

\section{Venezuelan Cultural Analysis}

As a segue into the theoretical model, one must understand Venezuelan culture to understand how this transformation could occur. The Hofstede model and assessment of cultural components are as follows (see Figure 2):

- Individualism (Individualist versus Collectivist) wherein:

- Collectivism: people belong to in-groups (families, organizations, etc.) who look after them in exchange for loyalty.

- Individualism: people look after themselves and their immediate family

- Power-Distance (high versus low) is the extent to which the less powerful members of society accept that power is distributed unequally.

- Masculinity (high versus low)

○ Masculinity: the dominant values in society are achievement and success.

- Femininity: the dominant values in society are caring for others \& quality of life.

- Uncertainty Avoidance (high versus low) is the extent to which people feel threatened by uncertainty and ambiguity and try to avoid such situations.

- Long Term Orientation is he extent to which people show a pragmatic or future-oriented perspective rather than a normative or short-term point of view.

- Indulgence (Indulgence versus Restraint) The extent to which people try to control their desires and impulses. Relatively weak control is called "Indulgence" whereas relatively strong control is called "Restraint". 


\section{FIGURE 2 \\ HOFSTEDE'S CULTURAL COMPARISON}

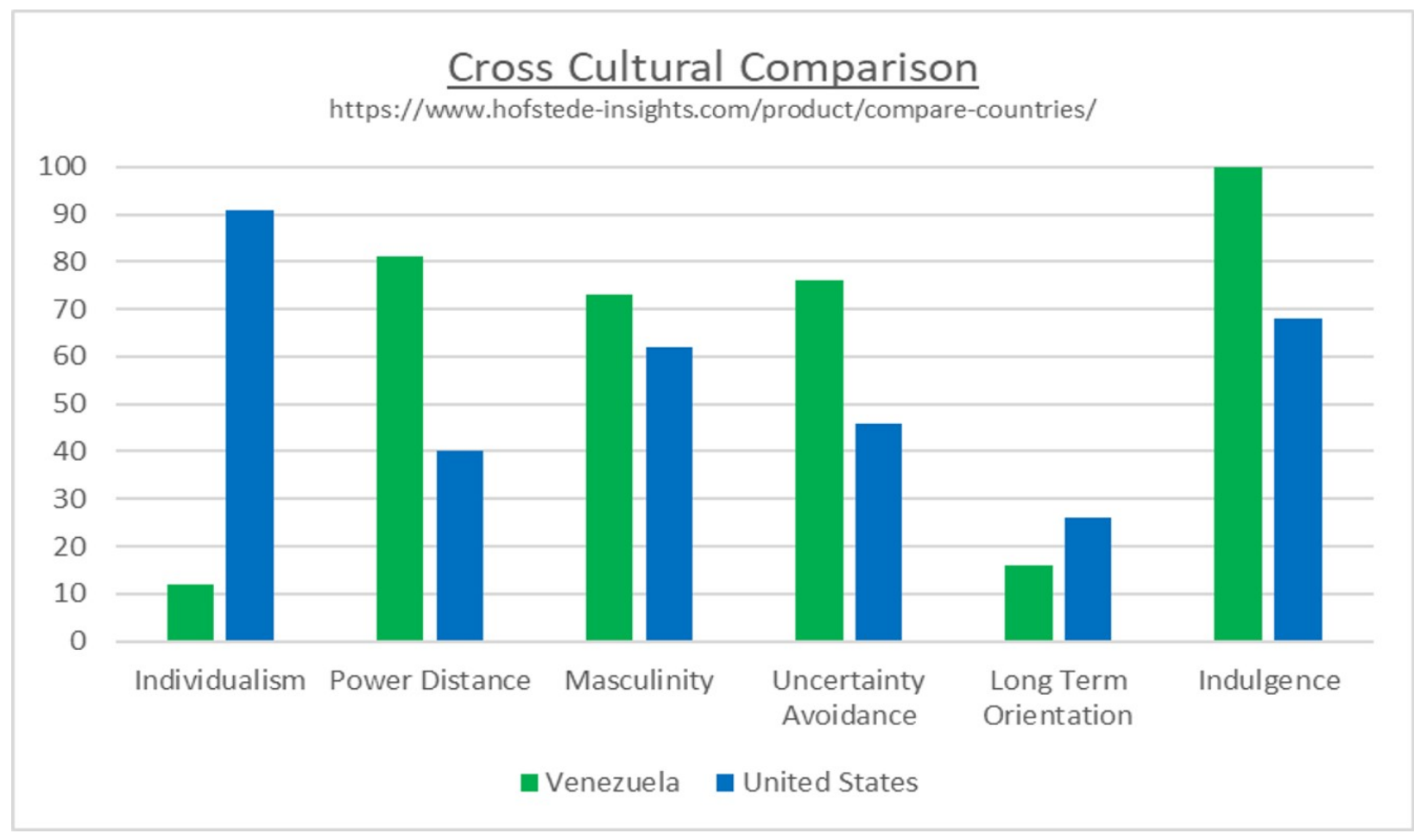

Based on Hofstede's research, the United States and Venezuela are opposite in Individualism and Power Distance ratings, which is important for our understanding of the República Bolivariana de Venezuela. Most citizens of the United States lean toward individualism where most people look after themselves and their immediate family and they also have a low power-distance orientation. In contrast, most Venezuelans lean toward collectivism, whereby people belong to in-groups (families, organizations, etc.) who look after them in exchange for loyalty; and they also score higher in power-distance where the less powerful members of society accept that power is distributed unequally (Hofstede, 2021).

Boris Saavedra $(2001 ; 2003)$ identified that military involvement in Venezuelan politics has been the norm for over 200 years; and that the poor in Venezuela accept strongman or caudillos-type leadership so long as the ruler takes care of the people from cradle to grave. This high-power-distance and cradle-tograve dependency upon government impacts upon the key actors within the theoretical model of the Bolivarian Republic to include:

- $\quad$ Elected officials (who are supported by the military)

- Citizens, the majority of whom were overwhelmingly poor

- The workforce (merit versus political cronies)

- Multi-National Corporations and other international customers (oil, cacao, etc.)

- Suppliers, both internal and external, to Venezuela

\section{THEORETICAL DEVELOPMENT MODEL}

This research was not as methodologically straight-forward as many quantitative studies, because grounded theory approach to synthesis and analysis seeks to tease out and define underlying relationships through an inductive and intuitive interpretation of the data (Baker, 2004, p.177). In addition, this case study assesses the Bolivarian Republic's experiment from a project and quality perspective rather than focusing exclusively upon political, social, or economic factors. 
FIGURE 3

AN ASSESSMENT MODEL FOR BOLIVARIAN $21^{\text {ST }}$ CENTURY SOCIALISM

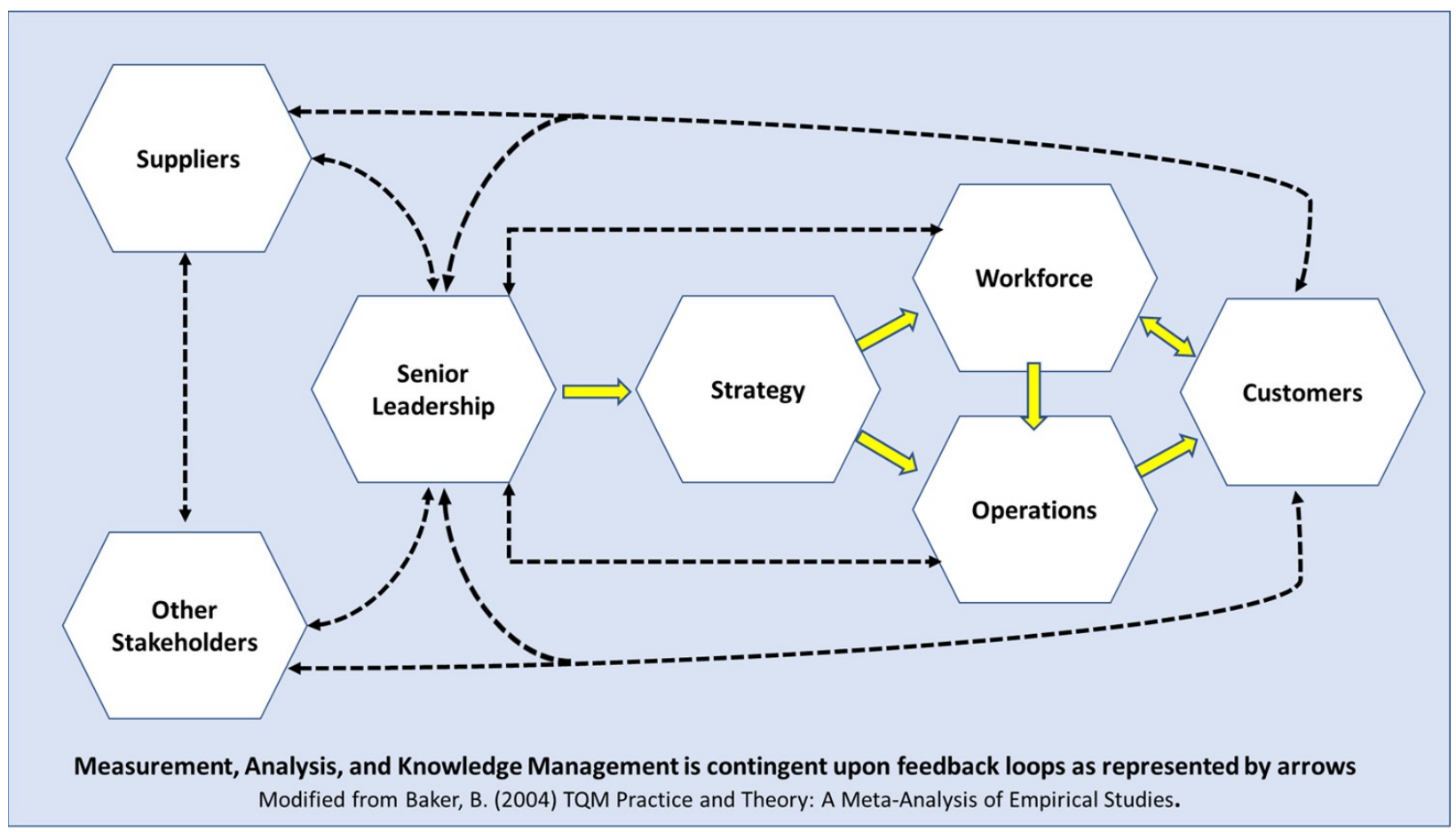

- The first category in this model consists of the senior leadership of the Venezuelan state, who developed strategies for the organization(s): senior leadership must demonstrate vision, values, and ethical behavior as well as legal, regulatory and community concerns; in addition, senior leaders develop communication loops that inform views from the customer, the workforce, the suppliers, and other stakeholders.

- The second category of this model is strategy; leaders must articulate how the workforce will accomplish key processes and how suppliers and resources support shorter term action plans.

- The third category is the workforce environment and engagement, which is focused upon education, training, and on-the-job reinforcement of knowledge and skills of an organization's employees (citizens) as well as their well-being.

- The fourth category is operations that entail work-processes and operational effectiveness.

- The fifth category is customer satisfaction with a product or service.

- The final category is measurement, analysis, and knowledge management, which is heavily contingent upon informational feedback loops.

- Finally, although "results" could comprise a stand-alone category, the author chose to include assessment of results in each of the afore mentioned categories.

\section{Research Questions}

Using this model, this paper investigated six Research Questions (RQ) to assess Chávez's Bolivarian Republic $21^{\text {st }}$ Century Socialism:

- RQ01 Leadership - How did Bolivarian senior figures lead and govern the organization and make societal contributions?

- RQ02 Strategy - How did Bolivarian leaders develop and implement their strategy? 
- RQ03 Workforce - How did Bolivarian leaders build an effective and supportive workforce environment for retention and high performance?

- RQ04 Operations - How did Bolivarian leaders design, manage, and improve their key products or services, and work processes while ensuring effective management of their operations?

- RQ05 Customers - How did Bolivarian leaders engage their customers and determine products and services to satisfy their needs?

- RQ06 Measurement, Analysis, and Knowledge Management - How did Bolivarian leaders manage their information, and measure, analyze, and then improve organizational (state) performance?

\section{DATA ANALYSIS AND RESULTS}

\section{RQ01 Leadership - How Did Bolivarian Senior Leaders Lead and Govern the Organization and Make Societal Contributions?}

Undoubtably, Chávez was a charismatic leader for the República Bolivariana de Venezuela, but the question is "Was he an effective leader?" The literature review showed that Chávez was initially responsive to his base, hence he was overwhelmingly elected and reelected by the lowest socio-economic class of the Venezuelan population, because rightly or wrongly, he was viewed as the champion of the little guy.

Chávez's vision for Venezuela began with MBR-200, wherein he envisioned a strong Bolivarian democracy, that was opposed to political corruption, neoliberal economic policies, and foreign influences (Trinkunas, 2002). That vision remained relatively unchanged, however senior leaders must also demonstrate their commitment to legal and ethical behavior. As one can see from the HRW (Figure 4), Chávez failed in this commitment. The Chávez administration's political discrimination, suppression of the courts, oppression or control of the media, organized labor, as well as civil society did not create an environment for success (HRW, 2008).

Senior leaders must also ensure fiscal accountability by ensuring key compliance processes, measures, and goals to meet or surpass regulatory and legal requirements. Instead of regulatory and legal compliance, Chávez consistently looked for changes to the laws or constitution that would circumvent any obstacles to his political, economic, and social goals. Ethical principles are the foundation for culture and values, distinguishing right from wrong. Clearly articulated ethical principles, empower people to make effective decisions and serve as boundaries for organizational norms and prohibitions. How did he do? Not well. Venezuela once had the strongest economy in Latin America; yet the 2019-2020 National Survey of Living Conditions (Encuesta Nacional de Condiciones de Vida-ENCOVI), published by researchers at Andrés Bello Catholic University in Caracas, documents that Venezuelan poverty levels spiked during 2019, thereby rendering it the poorest country in Latin America and the Caribbean.

The Transparency International (TI, 2020) Corruption Perception Index (CPI) uses 13 different data sources reported by 12 different institutions, which capture perceptions of corruption. Venezuela went from a score of 2.7 with a rank of 44 out of 102 nations in 1997, prior to the Chávez presidency, to a score of $20 / 100$ with a rank of 160 out of 177 nations by the end of his regime - a dismal failure. Fiscal accountability is problematic both inside and outside of Venezuela. After Chávez created ALBA, he initiated foreign aid to Haiti through deep discounts in oil. Unfortunately, Haitian cooperation and follow through is suspect due to internal corruption and their limited ability to demonstrate development results and accountability, with growing skepticism that the Chávez 's pledge of $\$ 1.2$ billion will ever be repaid (Baranyi, et.al., 2015).

Whether in a socialist or a capitalist state, the financial solvency of the state, and the well-being of the citizens is crucial. Within a capitalist society, employers bid on employees based upon their talent: for instance, a certified engineer is more valuable than a waiter, so he/she will command a higher wage. But the Bolivarian leaders believed they could simply decree higher pay for low wage workers without 
repercussion. The cost-push inflation model identifies that as wages rise, so does consumers' spending power, leading the economy to heat up thereby spurring inflation; but higher wages also result in higher costs of production. In addition, some economists argue that raising the minimum wage artificially creates imbalances in the labor market thereby leading to inflation as well.

\section{FIGURE 4 HUMAN RIGHTS WATCH REPORT ON VENEZUELA}

\footnotetext{
1 Political Discrimination

a. Fired and blacklisted political opponents from some state agencies and from the national oil company;

b. Denied some citizens access to social programs based on their political opinions

c. Discriminated against media outlets, labor unions, and civil society in response to legitimate criticism or political activity.

2 The Courts

a. In 2004 Chávez signed legislation that made it possible for his supporters in the National Assembly to both pack and purge the Supreme Court

b. This packed Supreme Court subsequently fired hundreds of lower court judges

c. Failed to safeguard fundamental rights in prominent cases involving the media and organized labor.

3 The Media

a. Expanded the scope of insult laws, which punish disrespectful expression toward government officials, and toughened penalties for criminal defamation and libel;

b. Expanded and toughened the penalties of vaguely defined "incitement" provisions that allow for the arbitrary suspension of TV and radio channels;

c. Restricted public access to official information; and

d. Abused the state's control of broadcasting frequencies to threaten and discriminate against stations with overtly critical programming.

4 Organized Labor

a. Undermined workers' right to elect their representatives by requiring state oversight and certification of union elections;

b. Denied the right to bargain collectively to unions which do not receive state approval of election results;

c. Undermined workers' right to freely join the labor organization of their choosing by engaging in favoritism toward pro-government unions; and

d. Undermined workers' right to strike by banning legitimate strike activity and engaging in mass reprisals against striking oil workers

5 Civil Society

a. Subjected rights advocates to criminal investigations on groundless or grossly exaggerated charges;

b. Sought to discredit and undermine rights organizations through unfounded allegations of complicity in subversion;

c. Sought to exclude organizations receiving foreign funding from participation in international forums; and

d. Promoted legislation that would allow arbitrary state interference in rights organizations' fundraising and operations.
}

HRW. 2008. A Decade Under Chávez - Political Intolerance and Lost Opportunities for Advancing Human Rights in Venezuela, Human Rights Watch, Obtained 25 May 2021 from https://www.hrw.org/reports/2008/venezuela0908/

Yet, despite empirical studies that indicate minimum wage laws reduce employment in general, the Bolivarian Republic increased minimum wages 38 times since 1999 , for a $108,637 \%$ increase in wages. Acevedo and Cirocco (2017) identified that 100 Bolivars in 2007 would buy 288 eggs, whereas 
10 years later just one egg would cost 500 Bolivars. Another key indicator of citizen satisfaction with government policies is net migration, which is the net total of migrants during the period, defined as the total number of immigrants less the annual number of emigrants, including citizens and noncitizens (e.g., people vote with their feet)! Data includes five-year estimates, showing a departure from the Bolivarian Republic of 4,540 people in 1997; 22,740 in 2002; over 200,000 in 2007; over 431,000 in 2012 and departure of more than 3 million people in 2017. Mass migration is a key indicator of dissatisfaction with Chávez 's policies (World Bank, 2021).

\section{FIGURE 5 CORRUPTION PERCEPTION INDEX (CPI) RANK}

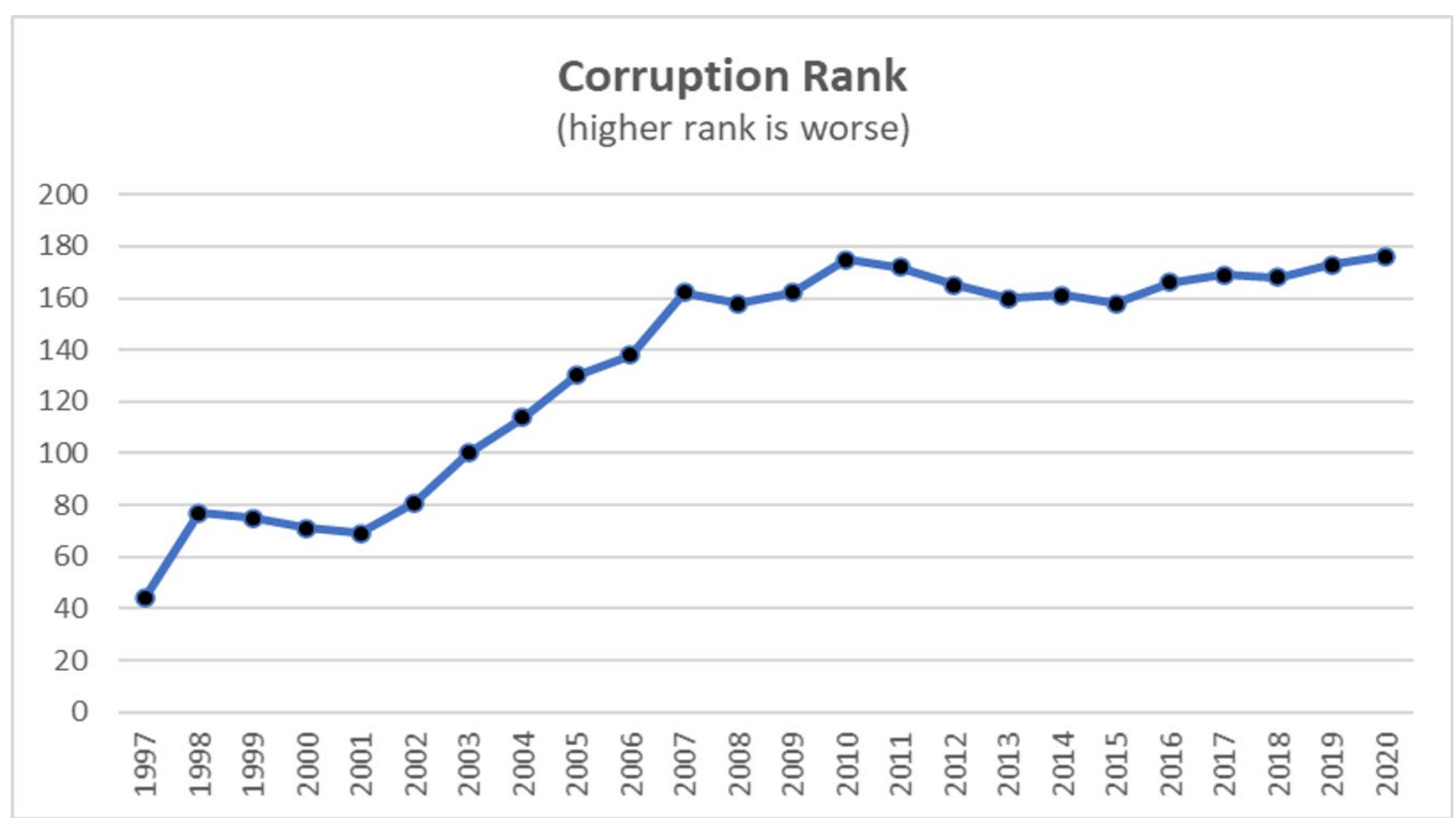

Transparency International, Corruption Perceptions Index, 2020 - CPI - Transparency.org

Chávez devalued the Venezuelan Bolívar (VEF), which served as a catalyst for mass migration out of the country. His devaluation of the VEF reduced the cost of exports (e.g., petroleum), making it more price competitive globally, but simultaneously increased the cost of imports (e.g., food). If imports such as food are more expensive, domestic Venezuelan consumers are less likely to purchase them, thereby strengthening the domestic agricultural businesses since imported goods become needlessly expensive. The official exchange rate in May 2002, was 1 VEF to 1 USD; it was raised to 6.2 VEF to 1 USD in 2013; and 9.975 to 1 USD in 2016. However, Bloomberg reports that the unofficial rate in late 2016 was 2,753 bolivars per U.S. dollar; but even worse, as of June 2021, \$1 USD $=309,239,024,714$ Venezuelan Bolívares. Devaluing the Bolivar was a bad decision for the Venezuelan population because purchasing power of the citizen and other consumers was immensely eroded.

\section{RQ02 Strategy - How Did Bolivarian Leaders Develop and Implement Their Strategy?}

Chávez did not establish his vision of $21^{\text {st }}$ Century Socialism until he had seven years in office. In addition, it took more two years to develop the Bolivarian government's National Development Plan (NDP) of 2007-13. So, for the first seven years of his presidency, many different plans, policies, and programs were initiated in ad-hoc fashion with few if any feedback loops. The literature review revealed 
that Chávez did not have a strong education in business fundamentals; hence, his lofty goals seldom translated into reality at each level:

- Strategic planning involves establishing a vision and conducting high-level, long-term planning with long-term objectives and priorities.

- Tactical planning is medium-term planning that applies strategic plans to specific functional areas.

- Operational planning is shorter-term planning that applies tactical plans to daily, weekly, and monthly operations.

For instance, Chávez articulated a strategic goal of food self-sufficiency; his tactical planning may have included plans for natural resources, capital, human resources, and entrepreneurship. Unfortunately, the concepts of cooperatives and missions, seldom turned into independent selfsufficiency. To compound this lack of strategic, tactical, and operational planning was a lack of feedback mechanisms to accurately report success or failure. Key timetables did not exist or if they did, they were not enforced; resources were not allocated in a timely manner or were never provided; a means to track achievement and effectiveness of action plans did not exist (Page, 2010; Upchurch, et.al., 2014; Ellner, 2010).

Strategically, cooperatives were seen as key to an endogenous model of economic development, that would raise people's living standards exempt of exploitation for true economic freedom. Did it happen? Nope. The Index of Economic Freedom is an annual guide published by The Heritage Foundation, which helps readers track advancement in economic freedom, prosperity, and opportunity. The Index covers 12 freedoms - from property rights to financial freedom - in 178 countries.

\section{FIGURE 6 \\ ECONOMIC FREEDOM}

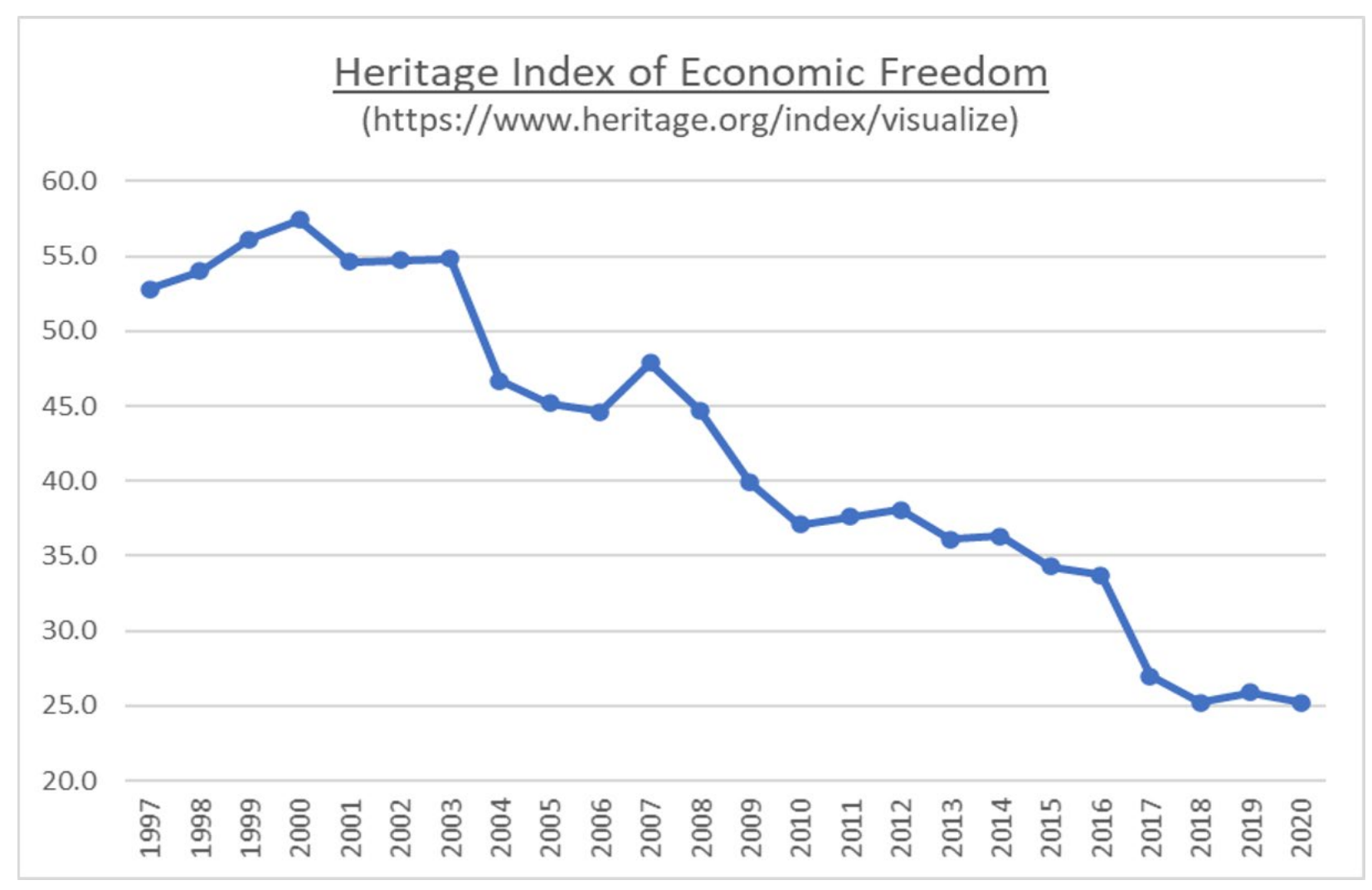


Figure 6 shows that Venezuela went from a high score of 57.4 in year 2000, to a very low score of 36.1 in 2013, as compared to 'the Americas' composite score of 60.8 points. This included an assessment of property rights, judicial effectiveness, government integrity, tax burden, government spending, fiscal health, business freedom, labor freedom, monetary freedom, trade freedom, investment freedom, and financial freedom. So, Chávez's Bolivarian economy harmed the citizens of Venezuela. The most repressed economies in the world out of 178 countries include Cuba (176), Venezuela (177), and North Korea (178) - yet each was envisioned as a Marxist-Socialist paradise.

\section{RQ03 Workforce - How Did Bolivarian Leaders Build an Effective and Supportive Workforce Environment for Retention and High Performance?}

Cooperatives were considered key to the success of the Bolivarian experiment; however, cooperatives often lacked training, resources, and infrastructure, in addition, they normally did not create enough revenue to play all workers nor reinvest in the business itself. Training that did occur was often considered substandard or lacking. In addition, there was animosity within cooperatives over wages for highly capable versus the untrained workers (Trinkunas, 2002; Gibbs, 2006; Gott, 2008; Avilés, 2009; Page, 2010; Rivers, 2011; Bruce, 2015).

Furthermore, rather than educating and training Venezuelan citizens in the medical fields, Chávez brought in 20,000 doctors and medics from Cuba, who were paid from oil revenues. In this fashion, Chávez's stated goal of reducing foreign influences merely switched from a level of inter-dependence with the United States to greater dependence upon Cuba. Rather than using Venezuelan oil profits to pay his own citizens, the money was going to Cubans without an appreciable increase in Venezuelan Workforce competencies (Ceasar, 2004; Gibbs, 2006; Britanica, 2013; Almandoz, 2017). In addition, there is a question of the competencies of Bolivarian leadership and Cuban medical staff since HIV, tuberculosis, Dengue, and Chagas diseases are not yet fully controlled; this is in part because authoritarian governments like Venezuela have greater constraints that make collaboration more difficult, particularly in policy areas where there is less devolution of power (Baracskay, 2013).

Workforce engagement relies upon senior leaders who foster an organizational culture that is characterized by open communication, high performance, and engagement. High performance in innately tied to a learning and development system that supports the personal development of workforce members and organizational needs. Chávez's two primary foci were the oil industry and agriculture. Since Chávez had fired the President of PDVSA and replaced 18,000 of long-serving petroleum professionals with his political followers, he was personally responsible for destroying the professionalism of PDVSA workforce (Parenti, 2006; Gates, 2014).

Chávez also intended to make Venezuela more self-sufficient in agriculture, however this lofty goal was highly dependent upon training urban people in agricultural production; yet initial volunteers for his agricultural program did not receive critical training and resources as promised (Page, 2010; Ellner, 2010; Upchurch, et.al., 2014; Wilde, 2018).

\section{RQ04 Operations - How Did Bolivarian Leaders Design, Manage, and Improve Their Key Products or Services, and Work Processes While Ensuring Effective Management of Their Operations?}

An assessment of operations consists of evaluating both work processes and operational effectiveness. Ground rent is the tribute paid from profits to the state for access to a non-reproducible natural resource; and Chávez's Bolivarian Republic was extremely dependent upon revenues from the oil industry (Purcell, 2017). However, despite massive increases in oil revenues between 1998 and 2008, his reinvestment into the Venezuelan 'golden goose' was neglected. Chávez's administration did not design, manage, or improve the key products and work processes within oil or agriculture; nor did they manage or improve supply networks. Hence, Venezuelan petroleum investment collapsed, oil infrastructure was falling apart, and production was in free fall (Smith, 2019).

Operational Effectiveness (OE) is how one manages the costs and efficiency of one's operations. A focus on $\mathrm{OE}$ could potentially improve cost, quality, and timeliness in every endeavor. Quality is the most 
cost effective, least capital-intensive route to productivity (Feigenbaum, 1991). Inherent in quality-based operational effectiveness is identifying the specific needs for improvement; establishing the infrastructure needed to secure continuous quality improvement; establishing a team for every project with clear responsibility for bringing it to conclusion; and providing resources, motivation, and training needed by teams (Deming, 1988; Feigenbaum, 1991; Juran, et.al., 1999). This detailed literature review has revealed absolutely no implementation of quality processes in Venezuela - a missed opportunity.

Another measure of $\mathrm{OE}$ is the ability to anticipate, prepare for, and recover from disasters, emergencies, and other disruptions. However, there have been major problems in sustaining electric power, despite Chávez's promise in the 2006 development plan to make Venezuela an energy superpower. Blackouts became routine throughout the country, which cast doubt on the government's ability to expand the productive base of the economy (Rosales, 2013).

\section{RQ05 Customers - How Did Bolivarian Leaders Engage Their Customers and Determine Products and Services to Satisfy Their Needs?}

Authoritarians need a real or perceived threat, so propaganda from the Chávez regime often denounced the United States, and even claimed the USA was involved in the 2002 attempted coup without any evidence (Ore, 2014; Kneuer, et.al., 2019). This caused strained relations between the two countries however, despite the rhetoric the United States has remained Venezuela's most important trading partner. Venezuela has been one of the top four suppliers of foreign oil to the United States, whereas American exports to Venezuela have included machinery, agricultural products, automobiles, and medical instruments.

\section{FIGURE 7 \\ US - VENEZUELA TRADE}

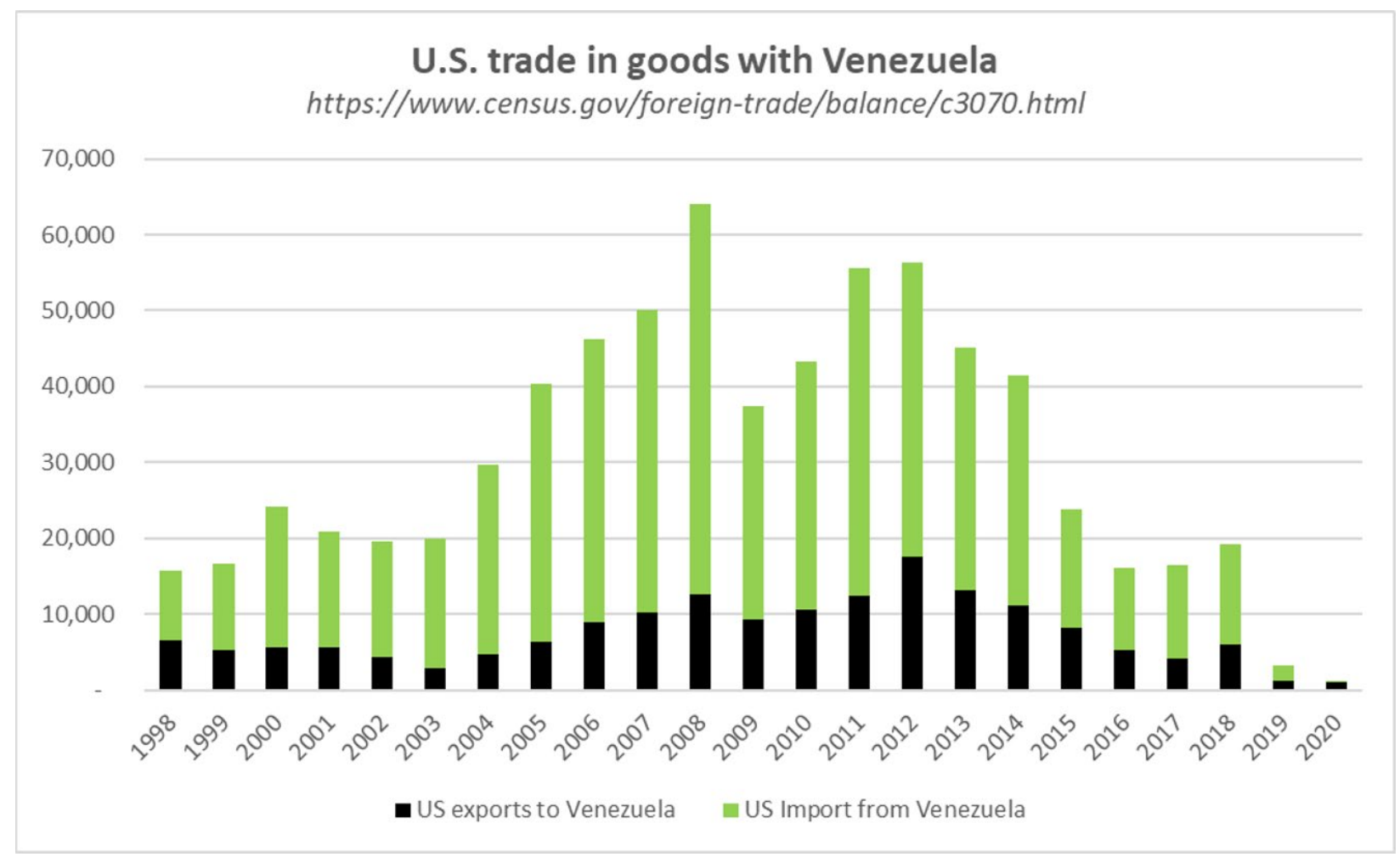

In this sense, the Bolivarian leaders have not listened to their American customers, nor did they modify products and services to meet new needs. This was not perceived as critical since Venezuela's primary export is petroleum; but customer engagement is focused upon building relationships with customers to 
determine their satisfaction and engagement, while resolving complaints promptly and effectively. Nonethe-less, the political diatribe directed against the United States would seemingly result in less trade, not more. A cursory review of the chart in figure 7 shows that trade with the United States continued to increase until 2008, experienced a pull-back in concert with the housing and banking crisis of 2009, and it rebounded by 2011 .

The other customers of the Bolivarian Republic are the citizens of Venezuela. Initial programs by Chávez regime focused solely upon the poor; hence, the middle class and upper-class entrepreneurs felt estranged from the regime, and many departed toward greener pastures. The poorer customers (citizens) were promised much, received much, and lost everything after regime overspending, currency devaluation, and subsequent massive inflation destroyed the Venezuelan economy.

Chávez demonstrated his hypocrisy by advocating opposition to foreign influences, while increasing trade with the United States and simultaneously expanding international relationships with China, Russia, Iran, and Cuba; he merely tried to replace one major power with several others. Hugo Chávez's efforts to radically transform the regional security order by building a Bolivarian alliance of states, as an explicit counterweight to U.S. power, completely fell short (Trinkunas, 2013; Vargas, 2014; Baranyi, et.al., 2015). ALBA was seen as an instrument of Chávez 's foreign policy to enhance his regional influence; however, ALBA programs like Petrocaribe in Haiti merely appear to be replacing Haitian dependency on the United States with dependency upon Venezuelan largesse (Baranyi, et.al., 2015).

\section{RQ06 Measurement, Analysis, and Knowledge Management - How Did Bolivarian Leaders Manage Their Information, and Measure, Analyze, and Then Improve Organizational Performance?}

To achieve efficiency and effectiveness leaders must measure, analyze, and then improve organizational performance; and this should not be a one-time measurement. Organizations should track data and information on daily operations and overall organizational performance to support fact-based decision making. Management by fact, not intuition, is critical to measure whether goals are being met (Baker, 2018; Baker, 2020).

The literature review revealed little to no planning for information flow, measurement, and analysis throughout the Bolivarian economy. The proposed assessment model shows information flows and critical relationships as follows:

- Senior leaders provide input and/or guidance to Strategy, Customers, Measurement, Analysis, and Knowledge Management, the Workforce, Operations and Results.

- Senior leadership impacts directly on employees and quality improvement.

- Employees (workforce) impact directly upon customer perceptions of quality service.

- Leadership-driven education and training impact upon workforce improvement.

- Employee development improves processes and operations management.

- Customers provide feedback to employees and leaders; as well as suppliers and other stakeholders.

- Suppliers interact with leaders, employees, and sometimes customers, as well as other stakeholders.

- Quality supplier inputs cascade into higher-quality product or service outputs.

- Employee feedback is needed to increase quality within the firm.

- Leaders and employees alike influence processes, plans and policies if employees are empowered.

- Quality products and services precede customer satisfaction.

- Customer satisfaction must precede positive financial results.

- Strategic Planning precedes planning and resourcing of Measurement, Analysis, and Knowledge Management.

- Measurement, Analysis, and Knowledge Management precedes operations improvements.

- Operations improvements must precede quality results. 
- Citizens are leader, members of the workforce, suppliers, customers, and other stakeholders, who had too great of a dependency upon centralized leadership.

The model in Figure 2 expresses these complex interrelationships. Unfortunately, these feedback mechanisms and critical support factors often did not exist before or after the Bolivarian experiment, within Cooperatives, Missions, Comites de Tierra Urbana (CTU) and communal councils (consejos comunales), or neighborhood associations that were envisioned as cornerstones of the bottom-up focus of Bolivarian socialism (Trinkunas, 2002; Gibbs, 2006; Gott, 2008; Avilés, 2009; Page, 2010; Rivers, 2011; Bruce, 2015).

Venezuela has large expanses of fertile land, but it depends on imports for around 70 per cent of its food, so in 2001 Chávez administration promoted a rural development plan. Based upon interviews with numerous participants, Page (2010) identified that:

- Senior Leadership encouraged development of agricultural cooperatives;

- Senior Leadership expropriated three million hectares of land; some was not fertile;

- The government placed people on farms who had little-to-no experience;

- Participants wanted more effective training;

- Poor soil quality made farming more difficult;

- There was a lack of effective technical support; visits were often not productive;

- Many farms were in isolated areas; hence transportation was an issue;

- Many farms were unimproved with no house, no potable, water, and no electricity;

- Trucks were promised but not delivered;

- Wells and irrigation systems were often postponed.

Page (2010) summarized that the Vuelta al Campo (VAC) program failed due to a lack of infrastructure, a lack of training, and a lack of experience. In addition, workers had to shift their thinking from 'wages in an urban capitalist system' to shared profits from a collective farm, that would not appear until produce was sold. Hence the original 117 families on 5 cooperatives shrunk to three cooperatives with just 16 individuals. Upchurch, et.al. (2014) identified that most cooperatives would not survive due to amateurism of the new farmers and government bureaucrats. This demise is in part a consequence of the lack of feedback mechanisms that permit effective measurement and analysis thereby dooming the future performance of agricultural cooperatives. Ellner (2010) determined that the Chávez movement had failed to systematically analyze experiences within worker-run companies.

The Bolivarian Republic's experiment did not develop effective 'Information \& Knowledge Management' with respect to either oil or agriculture. Critical success factors were not identified, and information was not on a deliberate feedback loop, therefore the availability of organizational data and information did not exist, and they were unable to share best practices. Yet, some of the cooperative successes were overtly propagandized but not reproduced elsewhere. For instance, the Association Civil Empresa Campensina Chuao was able to increase cacao production by $300 \%$ between 2005 to 2007 (Rivers, 2011). Azzellini (2009) and Rivers (2011) identified some other successes within the cocoa industry:

- Chocolates El Ray is a privately owned chocolate manufacturer that endorses Chávez's socially oriented policies.

- In 2010, the government assisted in the opening of El Cimmaron, which produces over two hundred thousand kilograms of chocolate every day

- The former employees of a bankrupt factory formed a cooperative (Unión Cooperativa Agro Industrial del Cacao), with a state financing at only 4 percent annual interest rate; they reopened it as a cooperative social production company - EPS (Empresa de Producción Social).

All three entities have the same goal which is production of high-quality chocolate and selling product overseas. So, even though Chávez 's aspiration was socialism at home, the cocoa market's reality was competition overseas. Yet information sharing among these entities has not been formalized. 


\section{DISCUSSION AND CONCLUSIONS}

Research concludes that Hugo Rafael Chávez Frías was not a visionary, but just another authoritarian, albeit populist, caudillo (Ellner, 2008; Gates, 2014). Chávez's early success was merely based upon nominal oil prices swelling from \$16.56 USD per barrel to \$91.48 USD per barrel between 1998 and 2008. Hence, it was luck, not talent, that funded government programs to lower unemployment rates and poverty levels, which had devastating reversals after oil prices dropped in 2009.

TABLE 1

ASSESSMENT RESULTS

\begin{tabular}{ll}
\hline Research Questions (RQ) for the Bolivarian Republic & Assessment \\
\hline RQ01 Leadership & Fail \\
- Human Rights Watch (Figure 4) & Fail \\
- Corruption Perception Index (Figure 5) & Fail \\
- Financial Solvency/Inflation & Temporary \\
- Higher Employment/Lower poverty & \\
RQ02 Strategy & Fail \\
- National Development Plan for 21st Century Socialism & Fail \\
- Food Self Sufficiency & Fail \\
- Economic Freedom (Figure 6) & \\
RQ03 Workforce & Fail \\
- Cooperatives & Fail \\
- Oil (Cronyism) & \\
RQ04 Operations & Fail \\
- Operational Effectiveness & Fail \\
-Quality Processes & \\
RQ05 Customers & Fail \\
- Improved Customer Relations & Fail \\
- Improved Regional Security & \\
RQ06 Measurement, Analysis, and Knowledge Management & Fail \\
-Improved Feedback Mechanisms & Fail \\
\hline
\end{tabular}

Hugo Chávez portrayed himself in the image of Simón Bolivar, but he did not come close. Instead, Chávez resembled former President Carlos Andrés Pérez Rodríguez who similarly experienced a huge increase in the price of oil during the 1970s; and like Pérez, Chávez had substantially increased government debt; established new state-owned companies; and nationalized the petroleum and other industries with long-term negative consequences.

Using grounded theory's constant comparative method, the author used qualitative analysis of data as the underlying method for the analysis of each research question. Based upon the proposed model in Figure 2, and the literature review, this analysis validates the use of a quality-based analysis. Chávez's administration efforts were analyzed in a dispassionate, non-political manner and the results are summarized as shown in Table 1.

If we reflect upon Chávez's speech in Vienna, he made two primary objectives for his Bolivarian Revolution to be (1) based in solidarity, fraternity, love, justice, liberty, and equality; and (2) be transformed 
from capitalism towards a new socialism. The first objective was not achieved as reported by both Human Rights Watch and Transparency International. By comparing Chávez's administration to Nolan's (2010) economic descriptions, Bolivarian Socialism is merely a state-centric socialist regime - not an innovative, albeit poorly defined $21^{\text {st }}$ Century Socialism.

\section{Implications}

One challenge in academic research is a stove-piped orientation to many topics: some of the politically correct universities admonish business professors from discussing politics in any form. However, political, social, and economic factors impact upon every business in existence, so a multi-disciplinary, grounded view was essential to this research.

There are very few studies focused on a business analysis of an administration or regime, with an emphasis on measurable outcomes; hence, this study is a valuable addition to the realm of business literature, policies, and practices. The assessment model and associated research questions will assist students of international business, as well as researchers for multinational corporations to conduct factbased assessments with a wide and inclusive context. More broadly, this work also contributes to theorizing the organizational links among leaders, workers, customers, suppliers, and other stakeholders.

\section{Limitations}

This research looked at the Bolivarian Republic using a modified a business model with total quality parameters of excellence. It includes an assessment of leadership, strategy, customers, workforce, and operations, as well as measurement, analysis, and knowledge management with the results in each category based upon an in-depth literature review. This is the major limitation to any meta-analysis because the conclusions, limitations, and implications are based upon others' peer-reviewed research. If senior leaders in any state were genuinely interested in efficiency and effectiveness to benefit their citizens, then a researcher could transparently ask questions of the administrative bureaucracy and develop qualitative and quantitative data for each government initiative. However, in as shown in Figures 4 and 5, human rights as well as corruption transparency were not high priorities among the senior leaders in the Bolivarian Republic. Hence, most research was not obtained directly from government representatives; and some data could be corrupted by propaganda from the regime.

\section{Future Scope}

The final frontier in project and quality management is an effective application to the not-for-profit and government sectors. Unlike government, for-profit businesses provide products or services to customers to make a profit - and in capitalism, a business ceases to exist if they do not have a satisfied customer base. In contrast, the Venezuelan government exists to provide services to the Venezuelan people as outlined in their Constitution. Therefore, the Venezuelan people can be considered clients, patrons, customers, or constituencies dependent upon which government employee to whom one speaks.

The Venezuelan government does not share the same market-driven motives as a multi-national corporation, nor does it have the same constituency as a not-for-profit entity. Instead, it is a massive bureaucracy, that is backed by the military, and has the power to raise revenues and spending with the stroke of a pen, while possessing a legal monopoly of certain services such as education, medicine, military, and the post office. But aside from these differences, corporations and a state government share many similarities. Both have senior leaders, professional managers, employees, processes, and unique cultures that define levels of service provided. Both are subjected to societal environmental factors such as economic, legal, political, technological, socio-cultural, and demographic factors. Therefore, despite these critical differences between the government versus profit-driven organizations, key lessons should theoretically be learned from one to benefit the other.

Chávez 's Bolivarian Republic started with lofty goals: the vision of a government that works better, costs less, to benefit their citizens. Without regard to the size of government, this cannot be achieved, without a quality improvement process using objective, measurable results: the bigger the project, the more important are the feedback loops that drive corrective actions. Based on the foregoing analysis, we 
recommend that future researchers use this model and associated research questions as a baseline for assessing measurable outcomes. Future research should focus upon longitudinal studies that would be replicated throughout different countries, not just to measure success or failure, but to answer "why" a government program did or did not achieve stated goals or objectives. Most critically, over-spending by the Chávez regime led to economic collapse and eventually one runs out of other people's money. The U.S. Congress should take note of this considering their massive national debt which has gone from $\$ 5.6$ trillion in 2001 to almost $\$ 30$ trillion in just 20 years, which is an unsustainable burden upon future generations (OMB, 2021). Like the República Bolivariana de Venezuela, overspending and debt will reduce the U.S. to a failed state: the question is when?

\section{EPILOGUE}

Millions of Venezuelan citizens have departed Chávez's socialist utopia; but ironically, not one caravan of American socialists has emigrated into Venezuela. Similarly, the Cuban people have begun revolting against their socialist-authoritarian regime (World Bank, 2021; Neild-Ali, et.al., 2021). Chávez's Bolivarian Experiment shows a failure of humans to learn from the past - and a triumph of hope and change over fiscal reality. After all, Ludwig von Mises was prescient in his research on Europe and the failings of the former Soviet Union. The following quotes from Mises' research apply succinctly to República Bolivariana de Venezuela, as well as Cuba:

- "The avowal of socialist ideas is today the proof of a complete ignorance of the basic problems of economics" (Mises, 1957, p. 111).

- "The most powerful demagogic trick applied by the (socialist or) communist parties is to excite the envy of those with lower incomes against all those with higher incomes" (Mises, 1957, p. $65)$.

- "Those fighting socialism do not reject socialism because they envy the workers the benefits they could allegedly derive from the socialist mode of production. They fight socialism precisely because they are convinced that it would harm the masses in reducing them to the status of poor serfs entirely at the mercy of irresponsible dictators" (Mises, 1957, p. 49).

- "If we were to regard the Soviet (or Venezuelan) regime as an experiment, we would have to say that the experiment has clearly demonstrated the superiority of capitalism and the inferiority of socialism" (Mises, 1957, p. 113).

The U.S. education system has failed to teach economics as well as the historical analysis of the Cold War to our youngest generations. According to the Pew Research Center, 42\% of Americans expressed a positive view of socialism, with heaviest support from our youth (Hartig, 2019), hence an ignorance of history. According to Harvard's Black Book of Communism, an estimated 100 million people were murdered by the socialist regimes of the $20^{\text {th }}$ Century (Courtois, et al., 1999); in similar fashion, Human Rights Watch has documented torture, inhumane treatment, forced disappearances, arbitrary detentions, and extrajudicial killings by the Venezuelan regime (HRW, 2021). Sadly, the Latino philosopher George Santayana was correct when he said, those who cannot remember the past are condemned to repeat it.

\section{ACKNOWLEDGEMENTS}

The author wishes to acknowledge the tremendous insights of Dr. Boris Saavedra as well as Dr. Rafael A. Acevedo for speaking truth to power under extreme adversity. 


\section{REFERENCES}

Acevedo, R.A., \& Cirocco, L.B. (2017). How Socialism Ruined Venezuela. The Austrian, 3(5), 4-7.

Acevedo, R.A., Cirocco, L.B., \& Maria, L.S. (2019). Desocialization of Enterprises: Empowering Venezuelans. Quarterly Journal of Austrian Economics, 22(2), 1-9.

Almandoz, A. (2017). Segregation and conflict in post-modernist Caracas: From Pérez's Gran Venezuela to Chávez's Bolivarian Revolution. Planning Perspectives, 32(4), 623-637.

Artz, L. (2016). Political Power and Political Economy of Media: Nicaragua and Bolivia. Perspectives on Global Development \& Technology, 15(1/2), 166-193.

Avilés, W. (2009). Policy Coalitions, Economic Reform and Military Power in Ecuador and Venezuela. Third World Quarterly, 30(8), 1549-1564.

Azzellini, D. (2009). Venezuela's Solidarity Economy: Collective Ownership, Expropriation, and Workers Self-Management. Working USA, 12(2), 171-191.

Bak, L. (2001). Populism and Labor Relations in Venezuela. International Journal of Political Economy, 31(2), 78-98.

Baker, B. (2004). TQM Practice and Theory: A Meta-Analysis of Empirical Studies. Dissertation Abstracts International, Proquest, 65(1A), 206.

Baker, B. (2018). Project Quality Management Praxis and Theory. American Journal of Management, 18(3), 1-11.

Baker, B. (2020). Power, Leadership and Culture as Drivers of Project Management. American Journal of Management, 20(1), 1-11.

Baracskay, D. (2013). Comparative Federal Health Care Policy: Evidence of Collaborative Federalism in Pakistan and Venezuela. Journal of Health \& Human Services Administration, 36(2), 124-163.

Baranyi, S., Feldmann, A.E., \& Bernier, L. (2015). Solidarity forever? ABC, ALBA and South-South Cooperation in Haiti. Third World Quarterly, 36(1), 162-178.

Batta, G., Sucre-Heredia, R., \& Weidenmier, M. (2014). Political Connections and Accounting Quality under High Expropriation Risk. European Accounting Review, 23(4), 485-517.

Britannica, T. (Editors of Encyclopedia). (2013, September 12). Bolivarian Alliance for the Peoples of Our America. Encyclopedia Britannica. Retrieved July 15, 2021, from https://www.britannica.com/topic/Bolivarian-Alliance-for-the-Peoples-of-Our-America

Bruce, I. (2015). The Real Venezuela: Making Socialism in the 21st Century. Pluto Press, London.

Butgereit, B., \& Carden, A. (2011). Capitalism, Socialism and Calculation. Economic Affairs, 31(3), 4145.

Castillo, M. (2013). Venezuelan leader Hugo Chávez dies. CNN. Retrieved May 15, 2021, from https://www.cnn.com/2013/03/05/world/americas/obit-venezuela-Chávez/index.html

Cole, K. (2010). Jazz in the Time of Globalization: The Bolivarian Alliance for the Peoples of Our America. Third World Quarterly, 31(2), 315-332.

Courtois, S., Werth, N., Panne, J.L., Packowski, A., Bartosek, K., \& Margolin, J.L. (1999). The Black Book of Communism: Crime, Terror, Repression. Cambridge, MA: Harvard University Press.

DOS. (1999). Venezuelan Soldiers leave their barracks. U.S. Department of State, Wash D.C. Retrieved May 15, 2021, from http://www.state.gov/documents/organization/143547.pdf

Deming, W.E. (1988). Out of the Crisis. Cambridge: Massachusetts Institute of Technology.

Ellner, S. (2008). Rethinking Venezuelan Politics: Class, Conflict, and the Chávez Phenomenon. Boulder, CO: Lynne Rienner Publishers, Inc.

Ellner, S. (2010). The Perennial Debate over Socialist Goals Played Out in Venezuela. Science \& Society, 74(1), 63-84.

Faria, H.J. (2008). Hugo Chávez Against the Backdrop of Venezuelan Economic and Political History. Independent Review, 12(4), 519-535.

Feigenbaum, A.V. (1991). Total Quality Control (3rd ed.). New York: McGraw Hill Book Co.

Gates, L.C. (2014). Interest groups in Venezuela: Lessons from the failure of a Model Democracy and the rise of a Bolivarian democracy. Journal of Public Affairs, 14(3/4), 240-253. 
Gibbs, T. (2006). Business as unusual: What the Chávez era tells us about democracy under globalization. Third World Quarterly, 27(2), 265-279.

Gott, R. (2008). Venezuela under Hugo Chávez: The Originality of the Bolivarian Project. New Political Economy, 13(4), 475-490.

Gutierrez, A.S. (2017). Venezuela's Economic and Social Development in the Era of Chavism. Latin American Policy. Retrieved July 15, 2021, from https://www.researchgate.net/publication/320885380

Hamill, H.M. (1996). Caudillismo, Caudillo. In Encyclopedia of Latin American History and Culture (Vol. 2, pp. 38-39). New York: Charles Scribner's Sons.

Hartig, H. (2019). Stark partisan divisions in Americans' views of socialism and capitalism. Pew Research. Retrieved August 11, 2021, from https://pewrsr.ch/2FxuzJ7

Hawkins, K. (2003). Populism in Venezuela: The rise of Chavismo. Third World Quarterly, 24(6), 11371160 .

Hollis, M.T., \& Denova, J.C. (2005). The History of Venezuela. Greenwood Publishing Group.

Hofstede, G. (2021). Venezuela - U.S. Country Comparison. Hofstede Insights. Retrieved August 1, 2021, from https://www.hofstede-insights.com/product/compare-countries/

Human Rights Watch. (2008). A Decade Under Chávez - Political Intolerance and Lost Opportunities for Advancing Human Rights in Venezuela. Retrieved May 25, 2021, from https://www.hrw.org/reports/2008/venezuela0908/

Human Rights Watch. (2021). Venezuela: Security Force Abuses at Colombia Border. Retrieved April 26, 2021, from https://www.hrw.org/news/2021/04/26/venezuela-security-force-abuses-colombiaborder

Juran, J.M., \& Godfrey, A.B. (1999). Juran's Quality Control Handbook(Vol. 5). New York: McGraw Hill Book Co.

Kneuer, M., Demmelhuber, T., Peresson, R., \& Zumbrägel, T. (2019). Playing the regional card: Why and how authoritarian gravity centres exploit regional organisations. Third World Quarterly, 40(3), 451-470.

Martin, J. (1911). An Attempt to Define Socialism. American Economic Review, 2, 347-354.

McCarthy-Jones, A., \& Turner, M. (2011). Explaining radical policy change: The case of Venezuelan foreign policy. Policy Studies, 32(5), 549-567.

Mises, L.V. (1957). The Best of Ludwig von Mises. American Institute for Economic Research. Kindle Edition.

Muhr, T. (2012). (Re)constructing Popular Power in Our America: Venezuela and the regionalization of revolutionary democracy in the ALBA-TCP space. Third World Quarterly, 33(2), 225-241.

Neild-Ali, K., \& Niemietz, K. (2021). Cuban uprising: What's next? Institute of Economic Affairs. Retrieved August 6, 2021, from https://ieapodcast.podbean.com/e/cuban-uprising-what-s-next/

Nelson, B.A. (2009). The silence and the scorpion: The coup against Chávez and the making of modern Venezuela. New York: Nation Books, pp. 1-8.

Nelson, B.A. (2021). Hugo Chávez. Encyclopedia Britannica. Retrieved July 15, 2021, from https://www.britannica.com/biography/Hugo-Chávez

Nolan, M. (2010). Classic Third Way or Before its Time? The New Zealand Labor Party in Local and Transnational Context. Labor History Review, 75(1), 98-113.

O’Grady, M.A. (2018). Venezuela's long road to ruin. Wall Street Journal. Retrieved May 21, 2021, from https://www.wsj.com/articles/venezuelas-long-road-to-hell-1528652625

OMB. (2021). Historical Debt - U.S. Government. Office of Management and Budget. Retrieved from https://www.whitehouse.gov/omb/budget/Historicals

Ore, D. (2014). Chavista' schoolbooks stoke passions in Venezuela. Reuters. Retrieved June 3, 2014.

Page, T.L. (2010). Can the State Create Campesinos? A Comparative Analysis of the Venezuelan and Cuban Repeasantization Programmes. Journal of Agrarian Change, 10(2), 251-272.

Patrinos, H., \& Sakellariou, C. (2005). Schooling and Labor Market Impacts of a Natural Policy Experiment. Review of Labour Economics \& Industrial Relations, 19(4), 705-719. 
Purcell, T.F. (2017). The political economy of rentier capitalism and the limits to agrarian transformation in Venezuela. Journal of Agrarian Change, 17(2), 296-312.

Ramirez, G.P. (2011). Estudio Histórico de la batalla de Carabobo (1821) (pp. 163-164). Universidad Andrés Bello, Instituto de Investigaciones Históricas.

Rivers, N.M. (2011). The Limits of Chávez's Bolivarian Socialism: Case Study of the Venezuelan Cacao Industry. Syracuse Journal of International Law \& Commerce, 39(1), 1-53.

Rosales, A. (2013). Going Underground: The political economy of the left turn in South America. Third World Quarterly, 34(8), 1443-1457.

Saavedra, B. (2001). Democracy At Risk: President Chávez and the New Role of the Armed Forces. Unpublished paper presented at LASA-XXXIII. Washington, D.C.

Saavedra, B. (2003). President Chávez and the new role of the Armed Forces, 1998-2001. Time and Space, 20(39). Caracas, Historical Research Center - Mario Briceño Iragorry.

Sangwani, P.N. (2016). Resource Nationalism in International Investment Law. New York: Routledge Taylor \& Francis Group.

Schroeder, G.E. (1991). The dismal fate of Soviet-type economies: Mises was right. CATO Journal, $11(1), 13$.

Smith, N. (2019). Venezuela economic collapse has lessons for America's socialists. Bloomberg.Com.

Sylvia, R.D., \& Danopoulos, C.P. (2003). The Chávez phenomenon: political change in Venezuela. Third World Quarterly, 24(1), 63-76.

Transparency International (TI). (2020). Corruption Perception Index. Retrieved June 26, 2021, from http://www.transparency.org

Trinkunas, H.A. (2000). Crafting Civilian Control in Emerging Democracies: Argentina and Venezuela. Journal of Interamerican Studies \& World Affairs, 42(3), 77.

Trinkunas, H.A. (2002). The Crisis in Venezuelan Civil-Military Relations. Latin American Research Review, 37(1), 41-76.

Trinkunas, H.A. (2013). Reordering Regional Security in Latin America. Journal of International Affairs, 66(2), 83-99.

Upchurch, M., Daguerre, A., \& Ozarow, D. (2014). Spectrum, trajectory, and the role of the state in workers' self-management. Labor History, 55(1), 47-66.

Vargas-Victoria, G.A. (2014). The Bolivarian Spring: What Are the Possibilities for Regime Change in Venezuela? Journal of International Affairs, 68(1), 269-283.

Vivoda, V. (2009). Resource Nationalism, Bargaining and International Oil Companies: Challenges and Change in the New Millennium. New Political Economy, 14(4), 517-534.

Wilde, M. (2018). To Fill Yourself with Goodness: Revolutionary Self-Making in Bolivarian Venezuela. Bulletin of Latin American Research, 37(2), 130-143.

World Bank (2021). Net migration for the Bolivarian Republic of Venezuela. Retrieved June 15, 2021, from https://fred.stlouisfed.org/series/SMPOPNETMVEN 